\title{
SNOWBALL THROWING SEBAGAI MODEL PEMBELAJARAN GUNA PENINGKATAN KEAKTIFAN BELAJAR SISWA MADRASAH IBTIDAIYYAH BIDANG MATEMATIKA
}

\author{
${ }^{1}$ Umi Musaropah, ${ }^{2}$ Muhamad Mahali, ${ }^{3}$ Daluti Delimanugari, \\ ${ }^{4}$ Muhammad Agus Najib, ${ }^{5}$ Mimi Indah Lestari, ${ }^{6}$ Muh. Nasruddin \\ ${ }^{1-5}$ STAI Yogyakarta Wonosari ${ }^{6}$ Universitas Cokroaminoto Yogyakarta \\ 1'mimusaropah@gmail.com, ${ }^{2}$ mmahali@ staiyogyakarta.ac.id, ${ }^{3}$ daluti@ staiyogyakarta.ac.id, \\ ${ }^{4}$ manajib@ staiyogyakarta.ac.id, ${ }^{5}$ milestari@ staiyogyakarta.ac.id, ${ }^{6}$ mohn98294@gmail.com
}

\begin{abstract}
Classroom action research was motivated by the less active attitude of the Class V students of MI Negeri 4 Gunungkidul. located in MI Negeri 4, located in Dusun Semenrejo, Pulutan Village, Wonosari District, Gunungkidul Regency in learning mathematics. The Snowball Throwing learning model is expected to be able to improve it, especially in the material of addition and subtraction of fractions with different denominators on. This research was conducted during July 2019. Data was collected through observation, interviews and documentation. The research was carried out for two sessions continuously to produce according to expectations where the achievement was achieved through learning as many as 22 students. Therefore it is suggested that the teacher can apply the SbT type of cooperative learning model to other materials. Variations can be made within the framework of cooperative learning that is adapted to the material and conditions.
\end{abstract}

Keywords: Snowball Throwing, cooperative learning, student activity, mathematics

\begin{abstract}
Abstrak
Penelitian tindakan kelas dilatarbelakangi dengan sikap kurang aktif dari para siswa Kelas V MI Negeri 4 Gunungkidul. berlokasi di di MI Negeri 4 berlokasi di Dusun Semenrejo Desa Pulutan Kecamatan Wonosari Kabupaten Gunungkidul dalam belajar matematika. Model pembelajaran Snowball Throwing diharapkan bisa meningkatkannya khususnya dalam materi Penjumlahan dan pengurangan pecahan dengan penyebut berbeda pada. Penelitian ini dilaksanakan selama bulan Juli 2019. Data dikumpulkan melalui observasi, wawancara dan dokumnerasi. Penelitian berjalan selama dua sesi secara berkelanjutan untuk menghasilkan sesuai harapan dimana pencapaiannya mencapai tuntas belajar sebanyak 22 siswa. Karena itu disarankan guru dapat menerapkan model pembelajaran kooperatif tipe SbT ke materi yang lain. Variasi dapat dilakukan dalam kerangka pembelajaran koperatif yang disesuaikan dengan materi dan kondisi.
\end{abstract}

Kata Kunci: Snowball Throwing, pembelajaran koperatif, keaktifan siswa, mathematik

\section{Pendahuluan}

Kerendahan daya tangkap siswa di bidang matematika bisa dikarenakan metode pengajaran dan keaktifan dari sisws. Keaktifan belajar merupakan unsur dasar yang penting bagi keberhasilan proses pembelajaran. Belajar aktif adalah "Suatu sistem belajar mengajar yang menekankan keaktifan siswa secara fisik, mental, intelektual, dan emosi guna memperoleh hasil belajar berupa perpaduan antara aspek kognitif, afektif, dan psikomotor" (Depdiknas, 2005, hal. 31). 
Oemar Hamalik, menyatakan bahwa keaktifan belajar siswa dapat kita lihat dari keterlibatan siswa dalam proses belajar mengajar yang beraneka ragam seperti pada saat peserta didik mendengarkan ceramah, mendiskusikan, membuat suatu alat, membuat tugas, dan sebagainya Hamalik, 2011, hal. 171). Trianto menyatakan bahwa "Hal yang paling mendasar yang dituntut dalam proses pembelajaran adalah keaktifan peserta didik" (Trianto, 2009). Keaktifan belajar siswa dalam proses pembelajaran akan menyebabkan interaksi yang tinggi antara guru dengan siswa ataupun antara siswa dengan siswa itu sendiri. Hal ini akan menimbulkan suasana kelas yang segar dan kondusif, dimana masing-masing siswa dapat melibatkan kemampuannya secara maksimal. Aktivitas siswa dalam proses pembelajaran tidak lain adalah untuk mengkonstruksi pengetahuan mereka sendiri. Terbentuknya pengetahuan dan keterampilan siswa akan mengarahkan pada peningkatan prestasi. Mc Keachie menyatakan berkenaan dengan prinsip keaktifan, mengemukakan bahwa individu merupakan manusia yang selalu aktif dan ingin tahu. Berdasarkan beberapa pendapat di atas dapat disimpulkan bahwa keaktifan belajar adalah segala kegiatan fisik maupun nonfisik yang dilakukan dalam proses pembelajaran untuk menciptakan suasana belajar yang kondusif sehingga siswa mampu mengoptimalkan kemampuannya (Dimyati \& Mudjiono, 2009, hal. 45).

Sarana belajar juga dapat mempengaruhi aktivitas belajar siswa. Sarana belajar terdiri atas ketersediaan runag kelas yang nyaman digunakan, media, dan sumber belajar yang memadai, serta kondisi lingkungan belajar yang mendukung. Ruang kelas yang nyaman adalah ruang kelas yang tidak terlalu sempit, ventilasi memadai, ruang yang ditata rapi dan ditambah dengan gambar-gambar yang dapat menarik siswa. Sekolah diharuskan menyediakan media maupun sumber belajar yang dapat menunjang kebutuhan siswa. Lingkungan belajar yang mendukung berupa keadaan dan jumlah guru yang memadai serta terciptanya keharmonisan dalam lingkungan sekolah. Dari pendapat-pendapat di atas, disimpulkan bahwa faktor-faktor yang mempengaruhi keaktifan belajar siswa dapat berasal dari guru maupun dari sarana belajar. Faktor dari guru berupa kemampuan guru dalam mengajar (keterampilan mengajar dan kemampuan mengembangkan model pembelajaran), sikap professional guru, dan latar belakang tingkat pendidikan dan pengalaman mengajar (Sanjaya, 2013, hal. 145-146). Make A Math adalah satu model pembelajarannya yang bisa dipilih untuk dikembangkan (Putri, 2020)

Pendidikan sekarang cenderung berpusat kepada murid dibanding guru (Fatihah \& Nadjih, 2017; Sarumaha, 2016). Siwa diorientasikan untuk aktif belajar mandiri dan guru berlaku sebagai fasilitator. Usia rata-rata siswa Madrasah Ibtidaiyah di Indonesia berkisar 
antara 6-12 tahun. Rentang usia tersebut lazimnya disebut sebagai masa anak (middle and late childhood) yakni suatu fase antara masa kanak-kanak (early childhood) dan masa remaja. Dalam periode usia yang bepikir secara operasional konkrit membutuhkan dibutuhkan suatu model pembelajaran tepat, menarik, dan efektif(Delimanugari, 2018).

Untuk mendorong keaktifan siswa kelas V MI Negeri 4 Gunungkidul, model pembelajaran yang akan digunakan adalah model pembelajaran Snowball Throwing (melempar bola, selanjutnya disebut SbT) yaitu suatu cara penyajian bahan pelajaran di mana siswa dibentuk dalam beberapa kelompok, kemudian masing-masing kelompok dipilih ketua kelompoknya untuk mendapat tugas dari guru lalu masing-masing siswa membuat pertanyaan yang dibentuk seperti bola (kertas pertanyaan) kemudian dilempar ke siswa lain yang masing-masing siswa menjawab pertanyaan dari bola yang diperoleh. Model pembelajaran SbT didesain semenarik mungkin dan menyenangkan bagi siswa dengan model diskusi kelompok dan interaksi antar siswa dari kelompok yang berbeda memungkinkan terjadinya saling sharing pengetahuan dan pengalaman dalam upaya menyelesaikan permasalahan yang timbul pada materi Matematika secara lebih interaktif dan menyenangkan guna untuk meningkatkan keaktifan belajar siswa pada mata pelajaran Matematika. Dengan model ini dapat juga membantu guru melatih kesiapan siswa SD dalam menanggapi dan menyelesaikan masalah (Agustina Tyas Asri Hardini \& Akmal, 2017; Lestari, 2017; Nurmalawati, 2009; Wahyu Ratriningsih, 2014; Wardhiana et al., 2018).

Strategi pembelajaran SbT merupakan pembelajaran adopsi pertama kali dari game fisik dimana segumpalan salju dilempar dengan maksud memukul orang lain. Dalam konteks pembelajaran, penerapannya dengan melempar segumpalan kertas untuk menunjuk siswa yang diharuskan menjawab soal. Strategi ini digunakan untuk memberikan konsep pemahaman materi yang sulit kepada siswa serta dapat juga digunakan untuk mengeahui sejauh mana pengetahuan dan kemampuan siswa dalam materi tersebut (Huda, 2015, hal. 226).

Pengembangan dari model pembelajaran diskusi dan merupakan bagian dari model pembelajaran kooperatif. Hanya saja, pada model ini kegiatan belajar diatur sedemikian rupa sehingga proses belajar mengajar dapat berlangsung dengan lebih menyenangkan (Shoimin, 2014, hal. 174). Tujuannya untuk menarik keaktifan siswa (Hermawan, 2016; Hidayati \& Weardani, 2020; Sarumaha, 2016). Metode ini bertujuan untuk memancing keaktifan berkreasi dalam membuat soal sekaligus menguji daya serap materi yang disampaikan oleh ketua kelompok. Kebebasan berfikir tanpa rasa takut salah dalam pembelajaran yang demikian sangat kondusif untuk memacu berfikir kreatif dan imajinatif (Suyadi, 2013, hal. 
105). Penerapan SbT dalam pembelajaran IPA siswa tidak hanya sekedar menerima informasi dari guru saja, karena dalam proses pembelajaran Cooperative Learning mengarahkan siswa belajar dengan mengembangkan minds-on activities (keterampilan intelektual) dan hands-on activities (keterampilan manual), learning by doing (belajar sambil berbuat) (Nurmalawati, 2009).

Kegiatan melempar bola pertanyaan ini akan membuat kelompok akan menjadi semangat dan aktif, karena kegiatan tersebut siswa tidak hanya berfikir, menulis dan bertanya atau berbicara akan tetapi juga melakukan aktifitas fisik yaitu menggulung kertas dan melemparnya kepada siswa lain. Dengan demikian tiap anggota kelompok akan mempersiapkan diri karena pada gilirannya mereka harus menjawab pertanyaan dari temannya yang terdapat dalam bola kertas. Langkah Langkah SbT. Sebagaimana pada umumnya, suatu metode pasti memiliki langkah-langkah dalam pembelajaran. Agus Supjono dalam Aris Susanti dalam (Shoimin, 2014, hal. 175-176) menjelaskan langkah-langkah metode $\mathrm{SbT}$ adalah sebagai berikut:

1) Fase I : Menyampaikan tujuan dan memotivasi siswa

Guru menyampaikan seluruh tujuan dalam pembelajaran dan memotivasi siswa.

2) Fase 2 : Menyajikan informasi Guru menyajikan informasi tentang materi pembelajaran siswa.

3) Fase 3 : Mengorganisasikan siswa kedalam kelompok-kelompok belajar Guru memberikan informasi kepada siswa tentang prosedur pelaksanaan pembelajaran SbT. Selanjutnya membagi siswa kedalam kelompok-kelompok belajar.

4) Fase 4 : Membimbing kelompok bekerja dan belajar Guru memanggil ketua kelompok dan menjelaskan materi serta pembagian tugas kelompok. Selanjutnya guru meminta masing-masing ketua kelompok untuk mendiskusikan tugas yang diberikan guru dengan anggota kelompok. Guru memberikan selembar kertas kepada setiap kelompok dan meminta kelompok tersebut menulis pertanyaan sesuai dengan materi yang dijelaskan guru. Guru meminta setiap kelompok untuk menggulung kertas tersebut berbentuk bola dan meminta untuk melemparkan kertas tersebut yang berisi pertanyaan kepada kelompok lain. Guru meminta setiap kelompok menuliskan jawaban atas pertanyaan yang didapatkan dari kelompok lain pada kertas kerja tersebut.

5) Fase 5 : Evaluasi Guru meminta setiap kelompok untuk membacakan jawaban atas pertanyaan yang diterima dari kelompok lain. 
6) Fase 6 : Memberi penilaian atau penghargaan Guru memberikan penilaian terhadap hasil kerja kelompok.

Kelebihan SbT yaitu: Suasana pembelajaran menjadi menyenangkan karena siswa seperti bermain dengan melempar bola kertas kepada siswa lain. Siswa mendapat kesempatan untuk mengembangkan kemampuan berpikir karena diberi kesempatan untuk membuat soal dan diberikan pada siswa lain Membuat siswa siap dengan berbagai kemungkinan karena siswa tidak tahu soal yang dibuat temannya seperti apa. Siswa terlibat aktif dalam pembelajaran.Pendidik tidak terlalu repot membuat media karena siswa terjun langsung dalam praktik. Pembelajaran menjadi lebih efektif. Ketiga aspek kognitif, afektif, dan psikomotor dapat tercapai.

Kekurangan SbT yaitu: Sangat bergantung pada kemampuan siswa dalam memahami materi sehingga apa yang dikuasai siswa hanya sedikit. Hal ini dapat dilihat dari soal yang dibuat siswa biasanya hanya seputar materi yang sudah dijelaskan atau seperti contoh soal yang telah diberikan. Ketua kelompok yang tidak mampu menjelaskan dengan baik tentu menjadi penghambat bagi anggota lain untuk memahami materi sehingga diperlukan waktu yang tidak sedikit untuk siswa mendiskusikan materi pelajaran. Memerlukan waktu yang panjang. Kelas sering kali gaduh karena kelompok dibuat oleh siswa.

\section{Metode Penelitian}

Penelitian tindakan kelas ini akan menginvestigasi model pembelajaran SbT dalam meningkatkan keaktifan belajar siswa pada mata pelajaran matematika dengan materi Penjumlahan dan pengurangan pecahan dengan penyebut berbeda pada Kelas V MI Negeri 4 Gunungkidul. berlokasi di di MI Negeri 4 Gunungkidul yang berlokasi di Dusun Semenrejo Desa Pulutan Kecamatan Wonosari Kabupaten Gunungkidul. Penelitian ini dilaksanakan selama bulan Juli 2019. Sasaran Objek penelitian adalah siswa kelas V MI Negeri 4 Gunungkidul. Pihak yang akan dijadikan sumber data dalam penelitian ini adalah Kepala Madrasah, Guru, dan siswa kelas V MI Negeri 4 Gunungkidul. Dengan penelitian ini diharapkan siswa mampu meningkatkan keaktifan belajar mata pelajaran Matematika dalam menggunakan model pembelajaran SbT. PTK (penelitian tindakan kelas) ini menjadi satu bentuk penyelidikan yang dilakukan melalui refleksi diri. Penelitian tindakan dilakukan peserta yang terlibat dalam situasi yang diteliti, seperti guru, siswa, atau kepala sekolah. Penelitian tindakan dilakukan dalam situasi sosial, termasuk dalam situasi pendidikan (Prihantoro \& Hidayat, 2019). Data dikumpulkan melalui observasi, wawancara dan dokumnerasi. Yaitu metode analisis dengan bertitik tolak pada data tersebut dengan metode 
atau cara pendekatan induktif dan deduktif. Induktif : menarik sebuah kesimpulan yang bermula dari masalah-masalah yang sifatnya khusus ke masalah-masalah bersifat umum. Deduktif : menarik sebuah kesimpulan yang bermula dari masalah-masalah yang sifatnya umum kemasalah yang bersifat khusus (Arikunto, 2017, hal. 42).

\section{Hasil dan Pembahasan}

Materi Matematika yang diajarkan dalam pembelajaran menggunakan SbT adalah Penjumlahan dan pengurangan pecahan dengan penyebut berbeda dengan rujukan pada buku siswa dari (Suparmin \& Rochma, 2017, hal. 7)

a. Penjumlahan pecahan dengan penyebut berbeda

Untuk menjumlahkan pecahan dengan penyebut berbeda, kita perlu menentukan KPK dari penyebutnya. Kemudian, menjumlahkan pecahan tersebut dengan cara menjumlahkan pembilangnya. Jika $\frac{a}{b}+\frac{c}{d}$, dengan $\mathrm{b} \neq \mathrm{d}$, maka untuk menyelesaikannya dapat dilakukan dengan tahapan berikut :

- Menentukan KPK dari penyebutnya, yaitu b dan d. Misal KPK adalah e.

- Menentukan nilai pecahan $\frac{a}{b}$ dan $\frac{c}{d}$ dalam bentuk pecahan berpenyebut e.

- Menjumlahkan pembilang kedua pecahan.

b. Pengurangan Pecahan dengan penyebut berbeda

Pengurangan pecahan dengan penyebut berbeda hampir sama dengan penjumlahan pecahan dengan penyebut berbeda. Kamu dapat menyelesaikan masalah pengurangan pecahan dengan penyebut berbeda. Caranya terlebih dahulu harus menentukan KPK dari penyebutnya.

Jika $\frac{a}{b}-\frac{c}{d}$ dengan $\mathrm{b} \neq \mathrm{d}$, maka untuk menyelesaikannya dapat dilakukan dengan tahapan sebagai berikut :

- Menentukan KPK dari penyebutnya, yaitu b dan d. Misalnya KPKnya adalah e.

- Menentukan nilai pecahan $\frac{a}{b}$ dan $\frac{c}{d}$ dalam bentuk pecahan berpenyebut e.

- Mengurangkan pembilang kedua pecahan tersebut.

Perlu diketahui bahwa penilaian yang dipakai untuk mengukur kemampuan siswa pada pembelajaran Matematika yaitu dengan penilaian KKM dan penilaian sikap. Penilaian sikap terdiri atas sikap sosial, kognitif, dan keterampilan. Sehingga dalam mengukur keaktifan belajar siswa menggunakan penilaian sikap sosial. Pada proses KBM tentu ada siswa yang tingkat keaktifannya rendah, maka tindak lanjut yang dilakukan yaitu dengan 
menggunakan berbagai macam model pembelajaran koopeartif salah satunya dengan menggunakan model pembelajaran SbT yang dapat menyenangkan bagi siswa dan siswa dengan mudah memahami apa yang kita ajarkan. Dengan model belajar berkelompok pada SbT, anak yang kurang aktif dalam belajar dibagi dan dikelompokkan dengan anak yang aktif sehingga memudahkan siswa dalam memahami materi yang disampaikan.

Efektivitas pembelajaran dengan menggunakan model pembelajaran SbT dalam meningkatkan keaktifan belajar siswa dapat dilihat dari hasil penerapan pembelajaran sebelum menggunakan model pembelajaran $\mathrm{SbT}$ dan sesudah menggunakan model pembelajaran SbT serta dapat dilihat dari hasil angket siswa dengan rincian sebagai berikut:

Tabel 1

Nilai Hasil Belajar Siswa Sebelum dan Sesudah Menggunakan Model Pembelajaran SbT

\begin{tabular}{|c|l|c|c|c|}
\hline NO & \multicolumn{1}{|c|}{ NAMA SISWA } & $\begin{array}{c}\text { Nilai } \\
\text { Pre } \\
\text { Test }\end{array}$ & $\begin{array}{c}\text { Nilai } \\
\text { Post } \\
\text { Test }\end{array}$ & $\begin{array}{c}\text { Peningkatan } \\
(\mathbf{\%})\end{array}$ \\
\hline 1 & Agil Ndaru Rinawang & 40 & 76 & $48 \%$ \\
\hline 2 & Agus dwi Susanto & 55 & 78 & $31 \%$ \\
\hline 3 & Alif Aliansyah & 78 & 80 & $3 \%$ \\
\hline 4 & Ayub Syahwanto Setiyawan & 60 & 79 & $25 \%$ \\
\hline 5 & Daffa Reza Narendra & 75 & 82 & $9 \%$ \\
\hline 6 & Dimas Ahmad Prasetyo & 43 & 77 & $45 \%$ \\
\hline 7 & Dyandra Nova Nino & 52 & 76 & $32 \%$ \\
\hline 8 & Farida Noor Kholifah & 76 & 82 & $8 \%$ \\
\hline 9 & Gadis Laura Permatasari & 79 & 89 & $13 \%$ \\
\hline 10 & Icha Vivi Liestyowati & 72 & 77 & $7 \%$ \\
\hline 11 & Indah Ramadhani & 50 & 75 & $33 \%$ \\
\hline 12 & Lathifah Tri At Mami & 76 & 80 & $5 \%$ \\
\hline 13 & Miftahul Jannah & 78 & 82 & $5 \%$ \\
\hline 14 & Muhammad Fahri Huseni & 45 & 78 & $44 \%$ \\
\hline 15 & Muhammad Raihan Rizki Yasmin & 60 & 84 & $32 \%$ \\
\hline 16 & Naura Husni Afifah & 52 & 78 & $35 \%$ \\
\hline 17 & Putri Meila Fitri Nurjannah & 40 & 75 & $47 \%$ \\
\hline 18 & Raditya Fadelio Akhdan & 56 & 79 & $31 \%$ \\
\hline 19 & Rafa Dwi Mahardika & 65 & 85 & $27 \%$ \\
\hline 20 & Rangga Eko Prasetyo & 45 & 76 & $41 \%$ \\
\hline 21 & Satria Avang Abizan & 72 & 86 & $19 \%$ \\
\hline 22 & Siti Uswatun Khasanah & 40 & 80 & $53 \%$ \\
\hline & Jumlah Nilai & $\mathbf{1 3 0 9}$ & $\mathbf{1 7 5 4}$ & \\
\hline & Nilai Rata-rata & $\mathbf{6 0}$ & $\mathbf{8 0}$ & $\mathbf{7 5 \%}$ \\
\hline & Nilai Tertinggi & $\mathbf{8 9}$ & \\
\hline & Nilai Terendah & $\mathbf{7 5}$ & \\
\hline & & & & \\
\hline
\end{tabular}


keaktifan siswa selama pembelajaran matematika dengan model SbT, membuktikan bahwa pembelajaran Matematika menggunakan model pembelajaran SbT lebih disukai dan digemari oleh siswa dibandingkan menggunakan metode yang cenderung monoton seperti metode tradisional yang menyebabkan kebosanan pada siswa. Hasil observasi yang membuktikan adanya peningkatan keaktifan siswa selama pembelajaran dengan menggunakan model pembelajaran SbT dapat dilihat melalui tabel berikut ini:

Tabel 3.5

Hasil Observasi Keaktifan Belajar Siswa pada Pembelajaran Matematika Menggunakan Model Pembelajaran SbT

\begin{tabular}{|c|l|c|c|c|}
\hline \multirow{2}{*}{ NO } & \multicolumn{1}{|c|}{ Perilaku yang diamati } & \multicolumn{2}{|c|}{ ASPEK PENELITIAN } \\
\cline { 3 - 5 } & & $\begin{array}{c}\text { Jumlah } \\
\text { siswa yang } \\
\text { diamati }\end{array}$ & $\begin{array}{c}\text { Jumlah } \\
\text { siswa } \\
\text { aktif }\end{array}$ & Prosentase \\
\hline 1 & Memperhatikan penjelasan guru & 22 & 21 & $95,45 \%$ \\
\hline 2 & $\begin{array}{l}\text { Semangat dan antusias dalam } \\
\text { pembelajaran }\end{array}$ & 22 & 21 & $95,45 \%$ \\
\hline 3 & Menuliskan catatan materi & 22 & 20 & $90,90 \%$ \\
\hline 4 & Bekerjasama dalam kelompok & 22 & 22 & $100 \%$ \\
\hline 5 & Berani untuk bertanya & 22 & 22 & $100 \%$ \\
\hline \multicolumn{2}{|l|}{$\begin{array}{l}\text { Rata-Rata Prosentase } \\
\text { Keaktifan Belajar Siswa }\end{array}$} & & $96,36 \%$ \\
\hline
\end{tabular}

Data terolah dari Observasi Keaktifan Siswa (2019)

Dari tabel tersebut dapat disimpulkan bahwa 96,36 \% siswa aktif selama pembelajaran Matematika menggunakan model pembelajaran SbT. Hal tersebut memberikan gambaran yang jelas bahwa upaya-upaya yang harus dilakukan oleh guru dalam pembelajaran Matematika yang pada dasarnya harus membungkus materi tersebut menggunakan metode-metode yang dapat dikatakan berhasil dalam meningkatkan keaktifan belajar siswa pada pembelajaran Matematika di MI Negeri 4 Gunungkidul.

\section{Penutup}

Penerapan pembelajaran Matematika model SbT belum menghasilkan hasil yang diharapkan pada sesi pertama, Dikarenakan waktu yang tersedia kurang, pembelajaran yang monoton, serta metode yang digunakan guru masih berpusat pada guru. Akibatnya keaktifan siswa dalam pembelajaran cenderung pasif, cepat bosan, dan mengikuti pembelajaran tidak menyenangkan. Selanjutnya penerapan pembelajaran matematika dengan perbaikan hasil evaulasi terbukti berhasil meningkatkan keakktifan siswa dengan hasil belajar matematika dengan mencapai tuntas belajar sebanyak 22 siswa. Diharapkan guru dapat menerapkan model pembelajaran kooperatif tipe SbT ke materi yang lain. Variasi dapat dilakukan dalam 
kerangka pembelajaran koperatif yang disesuaikan dengan materi dan kondisi. Hendaknya guru mampu mengalokasikan waktu dengan optimal pada waktu penerapan model pembelajaran SbT sehingga selama proses pembelajaran seluruh tahapan dapat diterapkan dengan baik.

\section{Daftar Pustaka}

Agustina Tyas Asri Hardini, \& Akmal, A. (2017). PENERAPAN METODE SNOWBALL THROWING BERBANTUAN MEDIA KONKRET UNTUK MENINGKATKAN KEAKTIFAN DAN HASIL BELAJAR IPA SISWA KELAS IV SEKOLAH DASAR. Jurnal Pendidikan Dasar PerKhasa, 3(1), 233-245.

Arikunto, S. (2017). Prosedur Penelitian Suatu Pendekatan Praktik. Rineka Cipta.

Delimanugari, D. (2018). Pengembangan Media Permainan Ilmu Pengetahuan Alam untuk

Meningkatkan Minat dan Hasil Belajar MI/ SD di Gunung Kidul Jogjakarta. FONDATIA, 2(2), 117-135. https://doi.org/10.36088/fondatia.v2i2.130

Depdiknas. (2005). Penilaian Hasil Belajar Peserta Didik Sekolah Dasar. Direktorat Pembinaan Sekolah Menengah Kejuruan.

Dimyati, \& Mudjiono. (2009). Belajar dan Pembelajaran. Rineka Cipta.

Fatihah, N., \& Nadjih, D. (2017). Hubungan Pendidik Dan Terdidik Dalam Al-Quran. Ulumuddin: Jurnal Ilmu-ilmu Keislaman, 7(2), 73-86.

Hermawan, T. (2016). PENGARUH KEMAMPUAN BERTANYA TERHADAP HASIL BELAJAR. Intersections : Jurnal Pendidikan Matematika Dan Matematika, 1(1), 5262. https://doi.org/10.47200/INTERSECTIONS.V1I1.521

Hidayati, I. S., \& Weardani, D. (2020). UPAYA MENINGKATKAN PRESTASI BELAJAR MATEMATIKA DENGAN METODE COOPERATIVE SCRIPT. Intersections : Jurnal Pendidikan Matematika Dan Matematika, 5(1), 30-37.

Huda, M. (2015). Model-Model Pengajaran dan Pembelajaran Isu-isu Metodis dan Paradigmatis. Pustaka Pelajar.

Lestari, M. (2017). Keefektifan Model Pembelajaran Snowball Throwing Berbantuan Cd Pembelajaran Terhadap Kemampuan. Jurnal KONSTANTA, 1(1).

Nurmalawati. (2009). Penerapan Model Cooperative Learning Tipe Snowball Throwing Untuk Meningkatkan Hasil belajar siswa pada Mata Pelajaran IPA Tentang Materi Energi Panas Dan Sifatnya. Journal Civics \& Social Studies, 3(1), 1-9. https://doi.org/10.31980/2655-7304.v3i1.585

Observasi Keaktifan Siswa. (2019). 
Prihantoro, A., \& Hidayat, F. (2019). Melakukan Penelitian Tindakan Kelas. Ulumuddin: Jurnal Ilmu-ilmu Keislaman, 9(1), 49-60.

Putri, P. O. (2020). Penerapan Model Pembelajaran Make A Math untuk Meningkatkan Keaktifan Belajar Siswa Pada Mata Pelajaran Matematika. Intersections: Jurnal Pendidikan Matematika Dan Matematika, 5(1), 15-20.

Sanjaya, W. (2013). Penelitian Pendidikan. Kencana.

Sarumaha, Y. A. (2016). Perubahan Pembelajaran Yang Berpusat Pada Guru Ke Berpusat Pada Siswa. Intersections, 1(1).

Shoimin, A. (2014). 68 Model Pembelajaran Inovatif dalam Kurikulum 2013. ArRuzzetenna.

Suparmin, \& Rochma, A. N. (2017). Buku Siswa Matematika Untuk SD/MI Kelas V. CV Mediatama.

Suyadi. (2013). Strategi Pembelajaran Pendidikan Karakter. PT Remaja Rosdakarya.

Trianto. (2009). Mendesain Model Pembelajaran Inovatif-Progresif: Konsep, Landasan, dan Implementasinya pada Kurikulum Tingkat Satuan Pendidikan. Kencana Prenada Media Group.

Wahyu Ratriningsih, M. S. W. I. (2014). Meningkatkan Keaktifan Belajar Siswa Melalui Model Pembelajaran Snowball Throwing Dengan Alat Peraga. EKUIVALEN Pendidikan Matematika, 7(3), 240-245. https://doi.org/10.37729/ekuivalen.v7i3.1033

Wardhiana, S., Sri Asri, A., \& Suniasih, W. (2018). PENERAPAN MODEL PEMBELAJARAN KOOPERATIF TIPESNOWBALL THROWING UNTUK MENINGKATKAN KEAKTIFAN DAN HASIL BELAJAR PKn KELAS V SD NEGERI 1 BUNGBUNGAN. MIMBAR PGSD Undiksha, 1(1). 